\title{
Kemampuan Berhitung Anak melalui Media Kartu Angka
}

\section{(Children's Ability in Calculating through Number Card Media)}

\author{
Dina Marselani \\ TK Kemala Bhayangkari 13 Padangsidimpuan \\ dinamarselani@gmail.com
}

$\begin{array}{ccc}\text { First received: } & \text { Revised: } & \text { Final Accepted: } \\ \text { 14 November 2019 } & \text { 20 November 2019 } & \text { 20 December 2019 }\end{array}$

\begin{abstract}
This research was conducted due to the low level of numeracy ability in children of group B in TK Kemala Bhayangkari 13 Padangsidimpuan. The formulation of the problem under study was how to improve children's numeracy skills through numeric media. The research conducted was classroom action research consisting of two observations, each of which consisted of 4 stages, namely planning, implementation, observation, and reflection. The subjects of this study were children of group B in TK Kemala Bhayangkari 13 Padangsidimpuan by using observation sheets. The data analysis used was qualitative data analysis techniques that can be seen from children's numeracy skills and quantitative data were calculated by formula. The results obtained in children's numeracy skills have increased. Before the action was taken, the level of numeracy ability of children was still very low, after the first cycle of research was obtained $44 \%$ and in the second cycle increased to $88 \%$. After conducting research starting from pre-cycle, cycle I, cycle II, it was concluded that the numeracy ability of group B children in TK Kemala Bhayangkari 13 Padangsidimpuan had increased.
\end{abstract}

Keywords: Numeracy, Media, Number Card

\begin{abstract}
Abstrak
Penelitian ini dilakukan karena rendahnya tingkat kemampuan berhitung pada anak kelompok B TK Kemala Bhayangkari 13 Padangsidimpuan. Rumusan masalah yang diteliti adalah bagaimana meningkatkan kemampuan berhitung anak melalui media kartu angka. Penelitian yang dilakukan adalah penelitian tindakan kelas yang terdiri dari dua observasi yang masing-masing terdiri dari 4 tahapan yaitu perencanaan, pelaksanaan, observasi, dan refleksi. Subjek penelitian ini adalah anak kelompok B TK Kemala Bhayangkari 13 Padangsidimpuan dengan menggunakan lembar observasi dan analisis data, yang digunakan yaitu teknik analisis data kualitatif yang dapat dilihat dari kemampuan berhitung anak dan data kuantitatif yang telah dihitung dengan rumus. Hasil penelitian yang diperoleh dalam kemampuan berhitung anak mengalami peningkatan. Sebelum dilakukan tindakan, tingkat kemampuan berhitung anak masih sangat rendah, setelah dilakukan penelitian siklus I diperoleh $44 \%$ dan pada siklus II meningkat menjadi $88 \%$. Setelah dilakukan penelitian mulai dari prasiklus, siklus I, siklus II, disimpulkan bahwa kemampuan berhitung anak kelompok B TK Kemala Bhayangkari 13 mengalami peningkatan.
\end{abstract}

Kata Kunci: Berhitung, Media, Kartu Angka 


\section{PENDAHULUAN}

Pendidikan anak usia dini adalah suatu upaya pembinaan yang ditujukkan kepada anak sejak lahir sampai dengan usia 6 tahun yang dilakukan melalui pemberian rangsangan pendidikan untuk membantu pertumbuhan dan perkembangan jasmani dan rohani agar anak memiliki kesiapan dalam memasuki pendidikan lebih lanjut. Salah satu kompetensi yang harus dimiliki oleh peserta didik PAUD adalah mampu mengikuti pendidikan selanjutnya dengan kesiapan obtimal sesuai dengan tuntutan kemampuan bahasa, fisik/motorik, seni dan kemampuan kognitif. Pengembangan kemampuan kognitif bertujuan meningkatkan kemampuan berfikir anak, yang mana anak diharapkan dapat mengenal konsep sains dan matematika sederhana.

Menurut Sujono (2008) kognitif adalah suatu proses kemampuan individu untuk menghubungkan, menilain dan mempertimbangkan suatu kejadian atau peristiwa. Berdasarkan observasi yang dilakukan oleh penulis di kelompok B TK Kumala Bhayangkari Padangsidimpuan menunjukkan bahwa kemampuan berhitung melalui media angka belum sesuai dengan perkembangan yang seharusya.

Berdasarkan hasil dari observasi yang telah dilakukan, permasalahan ini perlu adanya perbaikan dalam pembelajaran berhitung pada anak Kelompok B TK Bhayangkari Padangsidimpuan. Salah satu strategi yang dapat digunakan untuk menarik perhatian anak dalam belajar berhitung adalah dengan menggunakan media kartu angka.

Berhitung adalah bagian dari matematika yang diperlukan untuk menumbuhkembangkan keterampilan berhitung yang sangat diperlukan dalam kehidupan sehari-hari (Depdiknas, 2000). Menurut Sujono ddk (2008) menghitung merupan cara belajar mengenai angka kemudian menggunakan nama angka tersebut untuk mengidentifikasi jumlah benda. Menghitung suatu kemampuan akal untuk menjumlahkan.

Dari pengertian berhitung yang dikemukakan diatas dapat disimpulkan bahwa berhitung adalah cabang matematika yang berhubungan dengan bilangan dan berhitung terutama menyangkut penjumlahan, pengurangan, perkalian dan pembagian yang sangat diperlukan di kehidupan sehari-hari terutama konsep bilangan yang merupakan dasar dari pengembangan kemampuan matematika maupun kesiapan untuk mengikuti pendidikan dasar jadi ditaman kanak-kanak perlu adanya pengenalan lambang bilangan.

Sadiman, dkk. (2006), mengemukakan bahwa terdapat jenis media yang biasa digunakan di Indonesia yaitu: a) media grafis merupakan media visual yang sederhana, mudah, dan relatif murah untuk diperoleh, salah satunya adalah gambar atau foto. Cucu Eliyawaty (2005), mengemukakan bahwa media gambar atau visual adalah media yang sering digunakan oleh guru pendidikan anak usia dini untuk dapat menyampaikan isi dari tema pembelajaran yang sedang disampaikan; b) media audio yaitu media yang berkaitan dengan indra pendengaran. Media yang termasuk media audio antara lain radio, alat perekam pita magnetic, piringan hitam; dan c) media proyeksi diam yaitu media yang menyajikan rangsangan visual, namun media proyeksi harus diproyeksi dulu dengan proyektor agar dapat dilihat oleh sasaran. Jenis-jenis media proyeksi antara lain film bingkai, 
media transparansi, film, televise, dan video.

Dari uraian diatas dapat ditegaskan bahwa, media belajar adalah segala sesuatu yang dapat digunakan untuk memperjelas dan mempermudah materi atau pesan yang akan disampaikan guru ke anak, media belajar anak usia dini berwujud alat permainan, melalui alat permainan ini dapat merangsang minat serta motivasi anak untuk belajar. Jenis-jenis media ialah media grafis, media audio, dan media proyeksi diam. Berdasarkan jenis media yang digunakan di Indonesia, kartu kata bergambar merupakan media visual yang berbentuk kartu yang terbuat dari kertas karton dan mengandalkan panca indra penglihatan.Kata media berasal dari kata latin "Medius" tengah perantara dan pengantar menurut Djamarah (1995) media adalah alat bantu apa saja yang dijadikan sebagai penyalur pesan guna mencapai suatu tujuan pembelajaran. Menurut Purnawati dan Eldarni (2001) media merupakan salah satu yang dapat digunakan untuk menyalurkan suatu informasi sehingga dapat merangsang pikiran, perasaan, perhatian, dan minat anak sehingga terjadi proses belajar. Istilah media dalam bidang pembelajaran disebut juga media pembelajaran. Alat bantu/media tidak hanya dapat memperlancar proses komunikasi akan tetapi dapat merangsang anak untuk merespon dengan baik segala pesan yang disampaikan. Jenis media yang digunakan dalam meningkatkan pengetahuan untuk anak usia dini di antaranya adalah: a) media serutan kayu, b) media gambar, dan c) media kartu angka (Nurani, 2012).

Kartu angka atau alat peraga kartu adalah alat atau perlengkapan yang digunakan oleh seserang oleh guru dalam mengajari yang berupa kartu dengan bertuliskan angka sesuai dengan tema yang diajarkan (Nurani). Menurut
Tadkirotun (2012) kartu akan merupakan fasilitas penting dalam pembelajaran di sekolah karena bermanfaat untuk meningkatkan pengertian anak. Kartu angka adalah kotak yang berisi angkaangka yang dibuat diatas potongan karton dupleks berukan $5 \times 5 \mathrm{~cm}$. (Zaman dkk, 2008).

\section{METODE}

Penelitian ini dilaksanakan di TK Kemala Bhayangkari 13 Kec. Padangsidimpuan selatan kota padangsidimpuan pada kelompok B T.A 2018/2019. Subjek dalam penelitian tindakan kelas ini adalah siswa kelas B TK Kemala Bhayangkari 13 Padangsidimpuan selatan kota padangsidimpuan dengan jumlah siswa 16 anak yang terdiri dari 7 laki-laki dan 9 perempuan. Penelitian ini terdiri dari 2 siklus, siklus I dimulai dari tanggal 22 Oktober s/d 26 Oktober 2018, siklus II dimulai dari tanggal 29 s/d 02 November 2018. Objek dari penelitian ini adalah kegiatan penulis mengetahui sejauh mana antusias peserta didik dalam berhitung dengan menggunakan media kartu angka.

\section{HASIL TEMUAN DAN PEMBAHASAN}

Dari hasil kegiatan yang dilakukan oleh 16 orang anak yang BSB 4 orang dengan persentase $25 \%, \mathrm{BSH} 3$ orang dengan persentase $19 \%$, MB 2 orang dengan persentase $12 \%$, dan BB 7 orang dengan persentase $44 \%$ dengan demikian tingkat keberhasilan pelaksanaan kegiatan berhitung dengan menggunakan media kartu angka hanya (BSH dan BSB) $44 \%$. Hal itu menunjukkan tingkat keberhasilan dalam melakukan kegiatan berhitung dengan menggunakan media kartu angka masih tergolong rendah atau belum 
mencapai tingkat pengembangan yang diharapkan.

Dari hasil kegiatan yang dilakukan maka sudah terlihat bahwa kegiatan berhitung dengan menggunakan media kartu angka pada kegiatan siklus II menunjukkan perkembangan yang sangat baik dan telah mencapai tingkat perkembangan sesuai harapan yaitu $88 \%$. Dari 16 orang anak, yang BSB 11 orang dengan persentase $49 \%$, BSH 3 orang dengan persentase $19 \%, \mathrm{MB} 1$ orang dengan persentase $6 \%$, dan BB 1 orang dengan persentase $6 \%$. Dengan demikian dapat dinyatakan bahwa tingkat keberhasilan pelaksanaan kegiatan berhitung dengan menggunakan media kartu angka di TK Kemala Bhayangkari Padangsidimpuan berhasil dengan baik yaitu $88 \%$, sehingga perbaikan kegiatan berhenti pada siklus II dan tidak perlu lagi perbaikan siklus III.

\section{SIMPULAN}

Kesimpulan dari hasil penelitian yang diperoleh dapat diterapkan bahwa kegiatan berhitung dengan menggunakan media kartu angka dapat meningkatkan kemampuan berhitung anak, kegiatan tersebut diharapkan dapat mengembangkan kemampuan berhitung anak secara optimal.

Pelaksanaan metode perencanaan kegiatan serta pemilihan media yang menarik sangat membantu anak, sehingga anak lebih semangat dalam melakukan kegiatan berhitung dengan menggunakan media kartu angka yang dilakukan di TK Kemala bhayangkari 13 Padangsidimpuan.

\section{DAFTAR PUSTAKA}

Moleong, L. (2007). Dasar dasar Metodologi Penelitian. Bandung: CV.Tarsito

Arikunto, S. (2006). Prosedur Penelitian Suatu Pendekatan Praktek. Jakarta: PT. Rineka Cipta

Peraturan Menteri Pendidikan Nasional Nomor 20 Tahun 2003 tentang Standar Isi.

Djamarah, S. B. (2002). Strategi Belajar Mengajar. Jakarta: Rineka Cipta

Nurani, Y. (2002). Konsep Dasar Pendidikan Anak Usia Dini. Jakarta: PT. Indeks Sanjaya

Sujiono, Y. N., et. al. (2005). Metode Pengembangan Kecerdasan Majemuk. Tangerang: Universitas Terbuka

Tim PKP PG PAUD. (2008). Panduan Pemantapan Profesional. Jakarta: Universitas Terbuka

Zaman, B., et. al. (2005). Media dan Sumber Belajar TK. Jakarta: Universitas Terbuka

Tadkirotun, M. (2012). Pengembangan Kecerdasan Majemuk. Tangerang: Universitas Terbuka 